\title{
A Structural Model for Green Supply Chain Management relating the Antecedents of Green Supply Chain Management to its Adoption Practices
}

\author{
Prepared 6y \\ Dr. Rania Ramadan Moawad \\ Dina Ramadan \\ Canadian International College \\ drraniamoawad@hotmail.com \\ Sadat Academy for \\ Management Sciences \\ dinaramadan9@hotmail.com
}

Scientific Journal for Financial and Commercial Studies and Researches (SIFCSR)

Faculty of Commerce - Damietta University

Vol.3, No.1, Part 1., January 2022

APA Citation:

Moawad, R. R. and Ramadan, D. (2022). A Structural Model for Green Supply Chain Management relating the Antecedents of Green Supply Chain Management to its Adoption Practices, Scientific Journal for Financial and Commercial Studies and Research, Faculty of Commerce, Damietta University, 3(1)1. pp. 315-349.

Website: https://cfdj.journals.ekb.eg/ 
Scientific Journal for Financial and Commercial Studies and Researches

(SJFCSR) Faculty of Commerce - Damietta University

\title{
A Structural Model for Green Supply Chain Management relating the Antecedents of Green Supply Chain Management to its Adoption Practices
}

\author{
Dr. Rania Ramadan Moawad
}

\author{
Dina Ramadan
}

\begin{abstract}
:
Organizations started realizing the importance of green supply chain management (GSCM) for competitive advantages and sustainable environments. This paper is proposing a structural model relating the antecedents of GSCM to the adoption practices and implementations of GSCM. It starts by identifying an important set of GSCM antecedents and another set of implementation types and adoption practices and defining an initial structural model. Then a rigorous statistical analysis study is performed on data set collected from Egyptian electrical and electronic sector using two statistical models. The first model is called measurement model containing the descriptive statistics of all variables under study, and factor analysis to reduce this large number of variables. The second model is called structural model since it shows the structural relationship between the GSCM antecedents as independent variables and the GSCM implementation types as dependent variables. This structural model is based statistically on both univariate model and multivariate model. As a result of this detailed study some hypotheses are supported, and others are not supported (rejected) and this leads to a final structural model for green supply chain management.
\end{abstract}

Key words: Green Supply Chain Management, GSCM antecedents, GSCM adoption practices, Structural Model, Univariate Model, Multivariate Model. 


\section{Dr. Rania Ramadan Moawad \& Dina Ramadan}

\section{Introduction}

Organizations started realizing the importance of supply chain for competitive advantage, and business executives. Moreover, managers recognized that the ultimate success of any enterprise is no longer built around a firm's capability and capacity, but on a supply chain's capability and capacity (Gupta V et al., 2013 and Chow et al. 2008). One of the reasons for the increased interest in supply chain management is that the green supply chain management is the term that refers to the way in which organizational innovations and policies in supply chain management respond to the need for a more sustainable environment (Elting J 2009, Sarivastava 2007 and Cheng Ling Tan et. al, 2016). This involves the minimization of a firm's total environmental impact from the start to the end of a supply chain, and also form the beginning to the end of a product life cycle. (Routroy S, 2009; Mochamad A, et al., 2018 and Djunaidi, M. et al. 2018,) identified that greening the different phases of a supply chain leads to an integrated green supply chain, which ultimately leads to competitiveness and economic performance by reducing the environmental risks and by improving efficiency. In spite of the importance of GSCM, there are a lot of barriers face its implementation. These barriers are: Lack of top level management commitment, Lack of integration of information technology system, lack of skilled human resource professionals in GSCM, Lack of government initiatives system for GSCM practitioners, Lack of knowledge, experience and training to personals in GSCM, Cost of implementation for GSCM Supplier's flexibility to change towards GSCM, and Lack of customer's awareness towards GSCM and green products (Dashore K and Nagendra S, 2013; Abhijit Majumdar, Sanjib Sinha, 2018; Sunil Dhull , M.S. Narwal , 2016; Syed Shakil Ahmed, Tauhima Akter and Yuchao Ma, 2018) .

The research problem is that there's only a few initiatives to adopt GSCM in many organizations in Egypt. The majority of GSCM barriers concentrate on the unawareness of the necessary antecedents to adopt GSCM. What makes the situation more difficult is the shortage of studies on GSCM antecedents. Though there are a lot of studies about traditional supply chain management, studies on green supply chain management implementation are few. 
Scientific Journal for Financial and Commercial Studies and Researches

(SJFCSR) Faculty of Commerce - Damietta University

The reason behind this lack of implementation studies is ascribed to insufficient information about the way by which the greening implementation can be done. In order to define a way or an approach for implementing GSCM, it is necessary to clearly identify what its antecedents are.

This paper seeks to develop a structural model identifying the factors (antecedents) that are important for implementing a GSCM strategy and their impact in different adoption practices (implementation types). To achieve this purpose, this paper is following these steps:

- Identification of the most important GSCM antecedents based on an extensive literature review.

- Identification of main GSCM adoption practices and implementation types.

- Introduction of structural model relating the antecedents to adoption practices

- Deriving hypothesis from literature review

- Design of a survey (questionnaire) for data gathering concerning both GSCM antecedents, and GSCM adoption practices.

- Application of survey on Egyptian electrical \& electronics sector.

- Use of different statistical analysis models to check the data validity and reliability, and to find the impact of GSCM antecedents on GSCM adoption practices in the proposed structural model.

- Deduction of the verified structural model that shows the relationship between GSCM antecedents and GSCM adoption practices

\section{Literature review and theoretical framework}

\subsection{Literature review}

The literature review is summarized in the following table. 


\section{Dr. Rania Ramadan Moawad \& Dina Ramadan}

Table1: literature review

\begin{tabular}{|c|c|c|c|}
\hline $\begin{array}{l}\text { Researcher's } \\
\text { Name }\end{array}$ & Title & Main Topic & Conclusion \& Comments: \\
\hline $\begin{array}{l}\text { Joseph Sarkis } \\
-1999\end{array}$ & $\begin{array}{l}\text { How green is } \\
\text { the rupply } \\
\text { chain: practice } \\
\text { \& research }\end{array}$ & 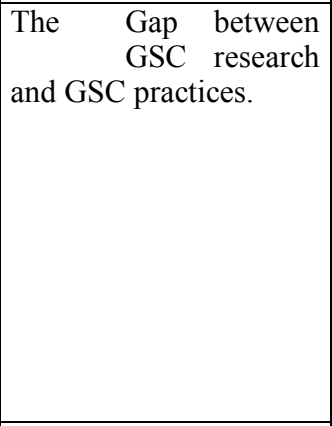 & $\begin{array}{l}\text { - Most of the literature has } \\
\text { investigated small portions of } \\
\text { the whole supply chain. With } \\
\text { only a few empirical studies. } \\
\text { - To truly address these } \\
\text { emerging debates and issues, } \\
\text { effective research agendas and } \\
\text { methodologies will be required } \\
\text { - So, it's a theoretical study } \\
\text { addressing the relationship } \\
\text { between academic research and } \\
\text { empirical studies. }\end{array}$ \\
\hline $\begin{array}{l}\text { M.K. } \\
\text { Chien \& } \\
\text { L.H. Shih } \\
-2007\end{array}$ & $\begin{array}{l}\text { An } \\
\text { cal study: } \\
\quad \text { the } \\
\text { implementation } \\
\text { of green supply } \\
\text { chain } \\
\text { management } \\
\text { practices in the } \\
\text { electricaland } \\
\text { electronic } \\
\text { industry and } \\
\text { their relation to } \\
\text { organizational } \\
\text { performances }\end{array}$ & $\begin{array}{l}\text { Investigation of the } \\
\text { green supply chain } \\
\text { management practices } \\
\text { adopted by the electrical } \\
\text { and electronic industry } \\
\text { in Taiwan. }\end{array}$ & $\begin{array}{l}\text { - The implementation of GSCM } \\
\text { practices has a positive effect } \\
\text { on environmental and financial } \\
\text { performance; that is, an } \\
\text { increase in environmental } \\
\text { performance will be } \\
\text { accompanied by increased } \\
\text { corporation profit and } \\
\text { market share. } \\
\text { - These conclusions effectively } \\
\text { dispel the doubts of those } \\
\text { corporations in Taiwan that } \\
\text { have not yet implemented } \\
\text { GSCM practices. }\end{array}$ \\
\hline $\begin{array}{l}\text { Stephan } \\
\text { Vachon - } 2007\end{array}$ & $\begin{array}{l}\text { Green } \\
\text { chain supply } \\
\text { es and the } \\
\text { selection of } \\
\text { environmental } \\
\text { technologies }\end{array}$ & $\begin{array}{|ll|}\text { Linking supply } & \text { chain } \\
\text { management } & \text { to } \\
\text { environmental } & \\
\text { technologies. } & \\
\end{array}$ & \begin{tabular}{|l} 
- Environmental collaboration \\
with suppliers is positively \\
associated with greater \\
investment in pollution \\
prevention technologies. \\
- Environmental \\
Collaboration with customers \\
has no impact on the adoption \\
\end{tabular} \\
\hline $\begin{array}{l}\text { Jens Elting } \\
-2009\end{array}$ & $\begin{array}{l}\text { Green supply } \\
\text { chain } \\
\text { management in } \\
\text { manufacturing } \\
\text { companies in } \\
\text { New Zealand: a } \\
\text { comparative } \\
\text { case study } \\
\text { analysis }\end{array}$ & 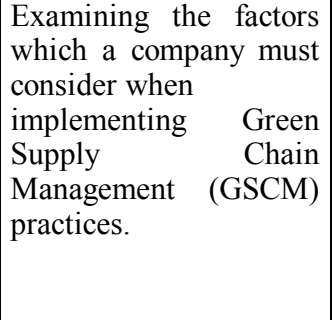 & $\begin{array}{l}\text { - Each examined company is in a } \\
\text { different situation with } \\
\text { different factors influencing } \\
\text { - their environmental approach. } \\
\text { - Nevertheless, one core } \\
\text { characteristic should be to } \\
\text { include the environmental } \\
\text { strategy in the general company } \\
\text { strategy to achieve consistency. }\end{array}$ \\
\hline
\end{tabular}


Scientific Journal for Financial and Commercial Studies and Researches (SJFCSR) Faculty of Commerce - Damietta University

\begin{tabular}{|c|c|c|c|}
\hline $\begin{array}{c}\text { Researcher's } \\
\text { Name }\end{array}$ & Title & Main Topic & Conclusion \& Comments: \\
\hline $\begin{array}{l}\text { Sirkanta } \\
\text { Routrooy } \\
-2009\end{array}$ & $\begin{array}{l}\text { Antecedents and } \\
\text { drivers for } \\
\text { green supply } \\
\text { chain } \\
\text { management } \\
\text { implementation } \\
\text { in } \\
\text { manufacturing } \\
\text { environment }\end{array}$ & $\begin{array}{l}\text { Proposing the } \\
\text { antecedents and drivers } \\
\text { of GSCM in a } \\
\text { manufacturing } \\
\text { environment. }\end{array}$ & $\begin{array}{l}\text { - The GSCM implementation in } \\
\text { the manufacturing environment } \\
\text { needs efforts from all corners. } \\
\text { - Greening the manufacturing } \\
\text { supply chain may result in one } \\
\text { or more benefits. }\end{array}$ \\
\hline $\begin{array}{l}\text { Jamal Fortes - } \\
2009\end{array}$ & $\begin{array}{l}\text { Green supply } \\
\text { chain } \\
\text { management: a } \\
\text { literature review }\end{array}$ & $\begin{array}{l}\text { Reviewing the literature } \\
\text { of the green supply } \\
\text { chain management } \\
\text { (GrSCM) over the last } \\
\text { twenty years. }\end{array}$ & $\begin{array}{l}\text { - There is a gap in the literature } \\
\text { in terms of the stakeholder } \\
\text { views towards green supply } \\
\text { chain management. } \\
\text { - Knowing the different } \\
\text { stakeholders 'views to greening } \\
\text { initiatives requires qualitative } \\
\text { study. }\end{array}$ \\
\hline $\begin{array}{l}\text { Ninlawan } \\
\text { C.,et.,al - } 2010\end{array}$ & $\begin{array}{l}\text { The } \\
\text { implementation } \\
\text { of green supply } \\
\text { chain } \\
\text { management } \\
\text { practices in } \\
\text { electronics } \\
\text { industry }\end{array}$ & $\begin{array}{l}\text { Examining the current } \\
\text { green activities in } \\
\text { computer parts' } \\
\text { manufacturers in } \\
\text { Thailand, and } \\
\text { evaluating green supply } \\
\text { chain management. }\end{array}$ & $\begin{array}{l}\text { - Collaborative among important } \\
\text { stakeholders in electronics } \\
\text { industry must be strongly } \\
\text { concerned. } \\
\text { - Some important suggestions are } \\
\text { noted here: promote eco- } \\
\text { design, control hazardous } \\
\text { substances, promote product } \\
\text { service system. }\end{array}$ \\
\hline $\begin{array}{l}\text { Ashish Bhatija } \\
\text { et.,al }-2011\end{array}$ & $\begin{array}{l}\text { Study of green } \\
\text { supply chain } \\
\text { management in } \\
\text { the Indian } \\
\text { manufacturing } \\
\text { industries: a } \\
\text { literature review } \\
\text { cum an } \\
\text { analytical } \\
\text { approach for the } \\
\text { measurement of } \\
\text { performance }\end{array}$ & $\begin{array}{l}\text { Studying the various } \\
\text { activities of the supply } \\
\text { chain processes of the } \\
\text { various } \\
\text { Manufacturing to find } \\
\text { how much eco-friendly } \\
\text { they are. }\end{array}$ & $\begin{array}{l}\text { - }[40 \%] \text { of Indian manufacturing } \\
\text { sectors Use electronic } \\
\text { processes to create efficiencies } \\
\text { in sourcing and procurement } \\
\text { - Cost and complexity are } \\
\text { perceived as the biggest } \\
\text { barriers to implementing } \\
\text { GSCM. } \\
\text { - Adoption of green practices is } \\
\text { highest in those areas of the } \\
\text { supply chain where there is a } \\
\text { direct relation to cost savings } \\
\text { and efficiency, } \\
\text { - [ } 64 \% \text { of companies are not } \\
\text { using e-tools extensively to } \\
\text { support their supply chain } \\
\text { Operations }\end{array}$ \\
\hline
\end{tabular}




\section{Dr. Rania Ramadan Moawad \& Dina Ramadan}

\begin{tabular}{|c|c|c|c|}
\hline $\begin{array}{l}\text { Researcher's } \\
\text { Name }\end{array}$ & Title & Main Topic & Conclusion \& Comments: \\
\hline $\begin{array}{l}\text { Hariram } \\
\text { Ranganath an } \\
\& \quad \text { Harishku } \\
\text { mar } \\
\text { Premkumar - } \\
2012\end{array}$ & \begin{tabular}{|l|} 
Improving \\
supply chain \\
performance \\
through lean \\
and green: a \\
study at Volvo \\
group India \& \\
Sweden
\end{tabular} & $\begin{array}{l}\text { Contribution to a further } \\
\text { understanding of the } \\
\text { supply chain } \\
\text { management, lean, } \\
\text { green and their } \\
\text { integration. }\end{array}$ & $\begin{array}{l}\text { - A theoretical frame work is } \\
\text { made so as to have a good } \\
\text { understanding about the } \\
\text { concepts and research work in } \\
\text { the relevant area. } \\
\text { - The empirical study at the } \\
\text { industries has been done to } \\
\text { examine their work practices } \\
\text { with lean and green in their } \\
\text { supply chain and the projects \& } \\
\text { initiatives. }\end{array}$ \\
\hline $\begin{array}{l}\text { Hassan M. } \\
\text { Elbeheiry et.,al } \\
-2012\end{array}$ & $\begin{array}{|lr|}\text { Drivers } & \text { and } \\
\text { barriers } & \text { facing } \\
\text { adoption } & \text { of } \\
\text { green r supply } \\
\text { chain rr } \\
\text { management in } \\
\text { egyptian food } \\
\text { and beverage } \\
\text { industry }\end{array}$ & $\begin{array}{l}\text { Identifying } \text { drivers and } \\
\text { barriers of GSCM } \\
\text { practices adoption in } \\
\text { Egyptian } \\
\text { Beverage }\end{array}$ & $\begin{array}{l}\text { - Organization values is the main } \\
\text { driver for adopting GSCM } \\
\text { practices in EFBI while lack of } \\
\text { resources and lack of } \\
\text { governmental support } \\
\text { represented the main barriers } \\
\text { facing adoption of GSCM } \\
\text { practices in EFBI. }\end{array}$ \\
\hline $\begin{array}{l}\text { Rajesh Kumar } \\
\text { \& Rituraj } \\
\text { Chandraka } \\
\text { r- } 2012\end{array}$ & $\begin{array}{l}\text { An overview of } \\
\text { green supply } \\
\text { chain } \\
\text { management: } \\
\text { operation and } \\
\text { environmental } \\
\text { impact at } \\
\text { different stages } \\
\text { of the supply } \\
\text { chain } \\
\end{array}$ & $\begin{array}{l}\text { Emphasizing upon the } \\
\text { application of Supply } \\
\text { Chain Management and } \\
\text { adding the Green } \\
\text { component to it so as to } \\
\text { stress upon the need of } \\
\text { environment friendly } \\
\text { systems. }\end{array}$ & $\begin{array}{l}\text { - GSCM is inevitable if the Earth } \\
\text { is to be kept green and } \\
\text { appropriate methodology may } \\
\text { be adopted by the } \\
\text { industries/services to minimize } \\
\text { the detrimental effect on the } \\
\text { environment. }\end{array}$ \\
\hline $\begin{array}{l}\text { Arvind } \\
\text { Upadhaya y - } \\
2012\end{array}$ & \begin{tabular}{|lr|}
\multicolumn{2}{|l|}{ Antecedents and } \\
enablers & of \\
green r & supply \\
chain practices
\end{tabular} & $\begin{array}{l}\text { Describing } \\
\text { antecedents the } \\
\text { enablers for green } \\
\text { supply chain practices. }\end{array}$ & $\begin{array}{l}\text { - Development of macro model } \\
\text { of green supply chain practices } \\
\text { with the inputs from literature. } \\
\text { - The synthesis of ten core green } \\
\text { supply chain practices with } \\
\text { antecedents and enablers from } \\
\text { existing body of literature } \\
\text { enriched through empirical } \\
\text { testing. }\end{array}$ \\
\hline $\begin{array}{l}\text { Muchiri } \\
\text { Kangangi } \\
-2013\end{array}$ & \begin{tabular}{|l|} 
Green supply \\
chain \\
implementation: \\
best practices \\
and challenges
\end{tabular} & $\begin{array}{l}\text { Fnding the best } \\
\text { practices that can } \\
\text { applied in green supply } \\
\text { chain strategies. }\end{array}$ & $\begin{array}{l}\text { - For a successful and } \\
\text { sustainable GSC } \\
\text { - implementation n; and } \\
\text { integration of systems between } \\
\text { trading partners in the supply } \\
\text { chain is required, senior } \\
\text { management support is a must. }\end{array}$ \\
\hline Kshitij Dashore & suuply & Evaluating the barriers & - The barriers' nature is complex \\
\hline
\end{tabular}


Scientific Journal for Financial and Commercial Studies and Researches (SJFCSR) Faculty of Commerce - Damietta University

\begin{tabular}{|c|c|c|c|}
\hline $\begin{array}{l}\text { Researcher's } \\
\text { Name }\end{array}$ & Title & Main Topic & Conclusion \& Comments: \\
\hline $\begin{array}{l}\text { \& Nagendra } \\
\text { Sohani }-2013\end{array}$ & $\begin{array}{l}\text { chain } \\
\text { management: a } \\
\text { hierarchical } \\
\text { framework for } \\
\text { barriers }\end{array}$ & $\begin{array}{l}\text { to the implementation of } \\
\text { the green supply chain } \\
\text { management (GSCM) in } \\
\text { an organization. }\end{array}$ & $\begin{array}{l}\text { and interdependent; an } \\
\text { Interpretive Structural } \\
\text { Modeling (ISM) technique is } \\
\text { applied to develop a structural } \\
\text { model. Driving and dependence } \\
\text { power analysis (DDPA) is used } \\
\text { to classify and identify critical } \\
\text { barriers. }\end{array}$ \\
\hline $\begin{array}{l}\text { Vishal Gupta } \\
\text { et.,al - } \\
2013\end{array}$ & $\begin{array}{l}\text { Green supply } \\
\text { chain initiatives } \\
\text { by IT } \\
\text { companies } \\
\text { in India }\end{array}$ & $\begin{array}{l}\text { Exploring the green } \\
\text { initiatives followed by } \\
\text { the three major Indian } \\
\text { IT } \\
\text { companies to manage } \\
\text { their supply chain. }\end{array}$ & $\begin{array}{l}\text { - These green initiatives by the } \\
\text { companies also distinguish } \\
\text { them from their competitors } \\
\text { and help them to improve their } \\
\text { brand image. }\end{array}$ \\
\hline $\begin{array}{l}\text { Hsiao-Fan } \\
\text { Wang \& } \\
\text { Surendra } \\
\text { M. Gupta } \\
-2013\end{array}$ & $\begin{array}{l}\text { Green supply } \\
\text { chain } \\
\text { management } \\
\text { (product life } \\
\text { cycle approach) }\end{array}$ & $\begin{array}{lr}\begin{array}{l}\text { Identifying } \\
\text { importance of } \\
\text { green } \\
\text { engineering }\end{array} \\
\text { management } & \text { and } \\
\text { respect to enterprise } \\
\text { competence, } \\
\text { environmental } \\
\text { protection, } \\
\text { sustainability }\end{array}$ & $\begin{array}{l}\text { - A strategy oriented operation } \\
\text { module has been introduced, } \\
\text { under this module, a method } \\
\text { called CECF has been } \\
\text { developed. } \\
\text { - The introduced CECF is not } \\
\text { only able to provide a } \\
\text { promising solution to the "new } \\
\text { user" problem, but it also } \\
\text { facilitates marketing strategies } \\
\text { to be performed. }\end{array}$ \\
\hline $\begin{array}{l}\text { Sayed Hashemi } \\
-2014\end{array}$ & $\begin{array}{l}\text { A grey-based } \\
\text { carbon } \\
\text { management } \\
\text { model for green } \\
\text { supplier } \\
\text { selection }\end{array}$ & $\begin{array}{l}\text { Developing a grey- } \\
\text { based carbon } \\
\text { management model for } \\
\text { supplier selection in a } \\
\text { green supply chain }\end{array}$ & $\begin{array}{l}\text { - A novel grey-based approach } \\
\text { has proposed to deal with the } \\
\text { supplier selection problem. } \\
\text { - Also, it has proposed a novel } \\
\text { group decision-making } \\
\text { technique namely IGRA to deal } \\
\text { with many problematic } \\
\text { managerial situations. }\end{array}$ \\
\hline $\begin{array}{l}\text { M. K. Mishra } \\
\text { et al. (2019) }\end{array}$ & $\begin{array}{l}\text { Impact of SMEs } \\
\text { Green Supply } \\
\text { Chain Practice } \\
\text { Adoption on } \\
\text { SMEs Firm and } \\
\text { Environmental } \\
\text { Performance }\end{array}$ & $\begin{array}{l}\text { to examine the impact } \\
\text { of SMEs green supply } \\
\text { chain practice adoption } \\
\text { on SMEs firm and } \\
\text { environmental } \\
\text { performance in different } \\
\text { Industry Associations } \\
\text { and clusters in the } \\
\text { SMEs domain in South } \\
\text { India using two-step : } \\
\text { - a measurement model } \\
\text { to assess the validity } \\
\text { and reliability of the } \\
\text { measures, } \\
\text { - then structural model } \\
\text { was used to test the } \\
\text { proposed hypotheses. }\end{array}$ & $\begin{array}{l}\text { - The results indicate that green } \\
\text { purchasing impacts on SMEs } \\
\text { firm performance and } \\
\text { environmental performance, } \\
\text { and eco design impacts on } \\
\text { SMEs firm performance. }\end{array}$ \\
\hline
\end{tabular}




\section{Dr. Rania Ramadan Moawad \& Dina Ramadan}

\begin{tabular}{|c|c|c|c|}
\hline $\begin{array}{l}\text { Researcher's } \\
\text { Name }\end{array}$ & Title & Main Topic & Conclusion \& Comments: \\
\hline $\begin{array}{l}\text { M. S. Asif et } \\
\text { al. }(2020)\end{array}$ & \begin{tabular}{|lr} 
Adoption of \\
green supply \\
chain \\
management \\
practices \\
through \\
collaboration \\
approach in \\
developing \\
countries r e \\
From literature \\
review r to \\
conceptual \\
framework
\end{tabular} & $\begin{array}{l}\text { To analyze three strands } \\
\text { of GSCM literature: } \\
\text { Firstly, drivers and } \\
\text { pressures for the } \\
\text { adoption of GSCM were } \\
\text { studied and three high } \\
\text { priority drivers were } \\
\text { selected for the } \\
\text { conceptual model } \\
\text { namely government } \\
\text { regulations, customer } \\
\text { demands and supplier } \\
\text { performance. Secondly, } \\
\text { the GSCM practices and } \\
\text { their adoption benefits } \\
\text { relevant to the } \\
\text { developing countries } \\
\text { were reviewed resulting } \\
\text { in selection of four } \\
\text { promising practices; } \\
\text { eco-design, green } \\
\text { purchasing, green } \\
\text { manufacturing and } \\
\text { reverse logistics. After } \\
\text { that, the literature was } \\
\text { reviewed on application } \\
\text { of management theories } \\
\text { in GSCM to testify the } \\
\text { theoretical implications } \\
\text { of the model. }\end{array}$ & $\begin{array}{l}\text { - Presenting a conceptual model } \\
\text { that coincides with the systems, } \\
\text { institutional and diffusion of } \\
\text { innovation theories and } \\
\text { purposes high degree of } \\
\text { collaborations among foreign } \\
\text { and domestic firms, } \\
\text { governments, customers and } \\
\text { suppliers the base practices } \\
\text { - Identifying the } \\
\text { and drivers exclusive to the } \\
\text { developing countries. It also } \\
\text { purposes a collaboration } \\
\text { mechanism in a novel } \\
\text { conceptual framework to } \\
\text { integrate the foreign and } \\
\text { domestic firms under common } \\
\text { agenda of improving the } \\
\text { environment. }\end{array}$ \\
\hline $\begin{array}{l}\text { Chieh-Yu Lin } \\
\text { et al. }(2020)\end{array}$ & $\begin{array}{l}\text { Adoption of } \\
\text { Green Supply } \\
\text { Chain } \\
\text { Management } \\
\text { among SMEs in } \\
\text { Malaysia }\end{array}$ & $\begin{array}{l}\text { to integrate the } \\
\text { Diffusion of Innovation } \\
\text { (DOI) theory and } \\
\text { Technology, } \\
\text { Organization and } \\
\text { Environment (TOE) } \\
\text { theory to examine the } \\
\text { factors that affect the } \\
\text { adoption } \\
\text { of green supply chain } \\
\text { management (GSCM) } \\
\text { practices among SMEs } \\
\text { in Malaysia. Twelve } \\
\text { hypotheses were } \\
\text { developed based on the } \\
\text { integrating theories in } \\
\text { technology adoption } \\
\text { context. }\end{array}$ & 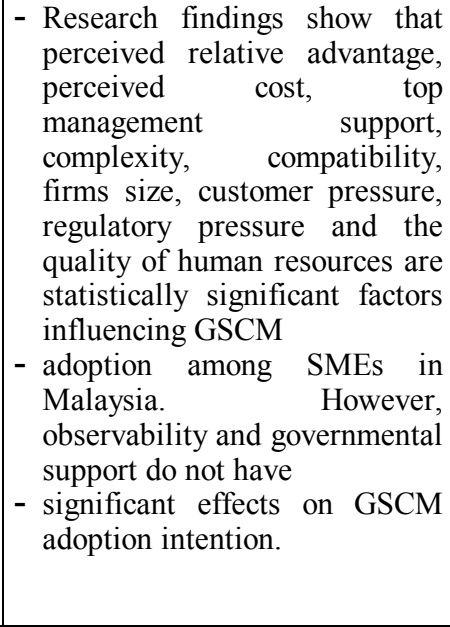 \\
\hline
\end{tabular}


Scientific Journal for Financial and Commercial Studies and Researches

(SJFCSR) Faculty of Commerce - Damietta University

\subsection{Antecedents of GSCM}

This paper identifies the most important GSCM antecedents based on literature review as follows:

\section{A. Top level management commitment to GSCM.}

Top management support and commitment is necessary for any strategic program success practices such as GSCM. (M.D. singh, 2012; Shreejith B., 2012; Soh Hyun et al., 2017), (Chieh- yu lin et al, 2020)

\section{B. Government support and regulations}

Government regulation can encourage or discourage the adoption of innovation, as Government sets the environmental regulations for industry (Xianbing Lui 2011, B.-Y. Chang et al. 2013; Zhijun Feng et al. , 2018 )

\section{High organizational culture (organization's internal culture)}

Management may encourage employees to learn green information. Organizations may provide rewards for green employees. Employees may be helped when they face green problems and may be provided support to learn green information (Yu Lin et al., 2008; Karen Wessels et al., 2018).

\section{Customer's awareness towards GSCM and green products}

A major antecedent of GSCM implementation is the awareness of customers about the benefits of green products, as Consumer's awareness about green products is important in guiding the green consumer purchasing behavior (B.P. Sharma 2015, Yi-Hui Ho et al. 2014)

\section{E. Supplier involvement}

Strengthen relationships with suppliers' results in lower inventory levels, costs and higher accuracy. Involvement of the suppliers in design process and technology affects overall performance of whole chain (Kannan et.al, 2010 and Juthathip Suraraksa et al., 2019)

\section{F. Gaining integrated GSCM.}

(Raganathan H and Premukar H, 2012 and Baofeng Huo, et al., 2019) argue that most firms implementing green supply chain practices 


\section{Dr. Rania Ramadan Moawad \& Dina Ramadan}

do not actually integrate environmental considerations into their supply chain management processes

\subsection{GSCM Adoption practices (Implementation types)}

The most important implementation types which considered here are:

\section{Type 1-Green Manufacturing and Packaging:}

For example, production focused on reducing waste, substitution of polluting and hazardous materials/parts, selection of cleaner transportation method, recycling and reusing packaging/container, and using ecological materials for primary packaging (Metters et al,2006), (M.S. Asif,2020).

\section{Type 2- Environmental Participation:}

For example, environmental training programs for employees, cross-functional cooperation for environmental improvements, commitment to green from upper management, Environmental Management System exists (King and Barker, 2007), (M.S. Asif, 2020).

\section{Type 3- Green Marketing:}

For example, sponsoring the environmental event with ecological organization, update label on packages, recuperation and recycling system, and update the website on environmental issues (Srivastava and Srivastava, 2006),

\section{Type 4- Green Suppliers:}

For example, suppliers' ISO 14000 certifications, supplier selection by environmental criteria, and collaborating green projects with suppliers (M.S.Asif, 2020), (Mishra et al, 2019).

\section{Type 5- Green Stock:}

For example, sales of excess capital equipment scrap and used materials (M.S.Asif, 2020), (Mishra et al, 2019).

\section{Type 6- Green eco-design:}

For example, design of products for reduced consumption of material/energy (Mishra et al, 2019). 
Scientific Journal for Financial and Commercial Studies and Researches

(SJFCSR) Faculty of Commerce - Damietta University

\subsection{Study hypotheses}

The paper tests several hypotheses as follows:

- Hypothesis 1: There is a relationship between top level management commitment to GSCM, and GSCM adoption practices (Implementation)

- Hypothesis 2: There is a relationship between Government support \& regulations, and GSCM adoption practices (Implementation).

- Hypothesis 3: There is relationship between High Organizational Culture (organization's internal culture), and GSCM adoption practices (Implementation).

- Hypothesis 4: There is no relationship between Customer's awareness towards GSCM \& green products, and GSCM adoption practices (Implementation).

- Hypothesis 5: There is relationship between Supplier Involvement, and GSCM adoption practices (Implementation).

- Hypothesis 6: There is a relationship between Gaining Integrated GSCM, and GSCM adoption practices (Implementation).

- Hypothesis 7: There is a relationship between all the proposed antecedents and GSCM implementation as a whole.

\section{3. initial structural framework}

An initial structural framework is given in figure 1 showing both of the identified antecedents and adoption practices (Implementation types) to be studied and verified using statistical analyses. 


\section{Dr. Rania Ramadan Moawad \& Dina Ramadan}

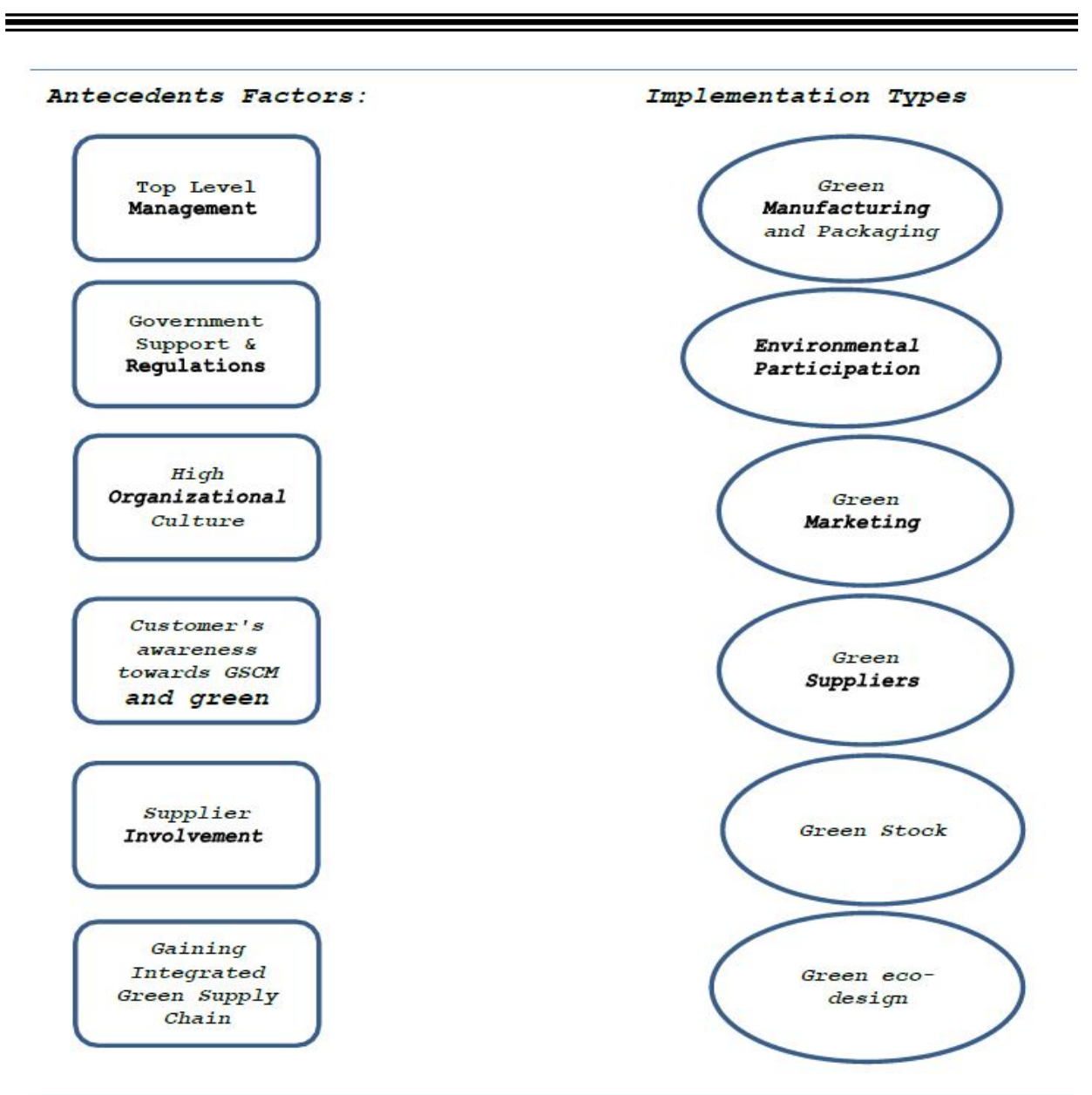

Figure 1: initial structural framework

\section{Statistical analyses}

\subsection{Instrument development method:}

Instrument development method for GSCM include three phases:

(1) item generation,

(2) reviewing the instruments of data collection, and

(3) Statistical analysis for instrument validity. 
Scientific Journal for Financial and Commercial Studies and Researches

(SJFCSR) Faculty of Commerce - Damietta University

Phase 1 which deals with item generation has to identify instruments that measure GSCM antecedents' factors and GSCM implementation types.

In Phase 2 of reviewing the instruments of data collection, the items were reviewed by three academicians and re-evaluated through structured interviews with three practitioners who were asked to comment on the appropriateness of the research constructs. Based on the feedback from the academicians and practitioners, redundant and ambiguous items were either modified or eliminated. New items were added wherever deemed necessary.

In phase 3 , a statistical analysis was used to determine the validity and reliability of the GSCM instruments.

\subsection{Data collecting and sampling unit:}

This study sought to choose respondents who are expected to have the best Knowledge about the operation and management of the supply chain in his/her organization. Based on literature and recommendations from practitioners it was decided to choose managers who are at higher $\&$ middle managerial levels as respondents for the current study. The respondents were asked to refer to their major suppliers or customers for relevant questions. The final version of the questionnaire, measuring all the items on a five-point scale, was administrated to target respondents. The questionnaire starting by an introduction indicating the purpose and significance of the study were mailed to the target respondents. These target respondents are three organizations working in the sector of electric \& electronic industry in Egypt. (Carrier, Power, Union-air).

There were 155 complete and usable responses. A significant problem with organizational-level research is that senior and executivelevel managers receive many requests to participate and have very limited time. Because of this interdisciplinary research collects information from several functional areas, the size and scope of the research instruments were too large and time consuming to complete. This interprets the size of obtained number of responses.

Of all respondents, almost $20 \%$ are $\mathrm{CEO} /$ President/Vice President/Director, and about half are managers, some identified 


\section{Dr. Rania Ramadan Moawad \& Dina Ramadan}

themselves as supply chain manager, plant manager, logistics manager or IT manager in the questionnaire.

The areas of expertise were $30 \%$ purchasing, $40 \%$ manufacturing production, and $30 \%$ distribution/transportation/ sales. It can be seen that respondents have covered all the functions across a supply chain from purchasing, to manufacturing, to distribution and transportation, and to sales. Moreover, about $30 \%$ of the respondents are responsible for more than one job function, and they are expected to have a broad view of GSCM practice in their organization, among the variables of GSCM.

\subsection{Overview of statistical analysis study:}

The next section presents the statistical analysis study. This study includes two models. The first one is called measurement model and the second is called structural model.

\section{The measurement model contains the followings:}

-Descriptive statistics such as frequency tables, means and standard deviations.

-Factor analysis for dimension reduction.

-Data analysis validity to measure the reliability of each factor.

\section{The structural model contains the following:}

-Multivariate model to find the relationships between all the GSCM antecedents' components and all the GSCM implementation types.

-Univariate model to find the relationships between all the GSCM antecedents' components and the GSCM implementation as one dependent variable.

\subsection{Results of statistical analysis study}

\subsubsection{Factor analysis results}

As a result of factor analysis, the 6 antecedent factors, each having 6 items (questions) represented by 36 variables are reduced to only 11 components. The initial structural framework is modified after the statistical factor analysis phase for the purpose of dimension reduction to be as given in figure 2 . 
Scientific Journal for Financial and Commercial Studies and Researches (SJFCSR) Faculty of Commerce - Damietta University

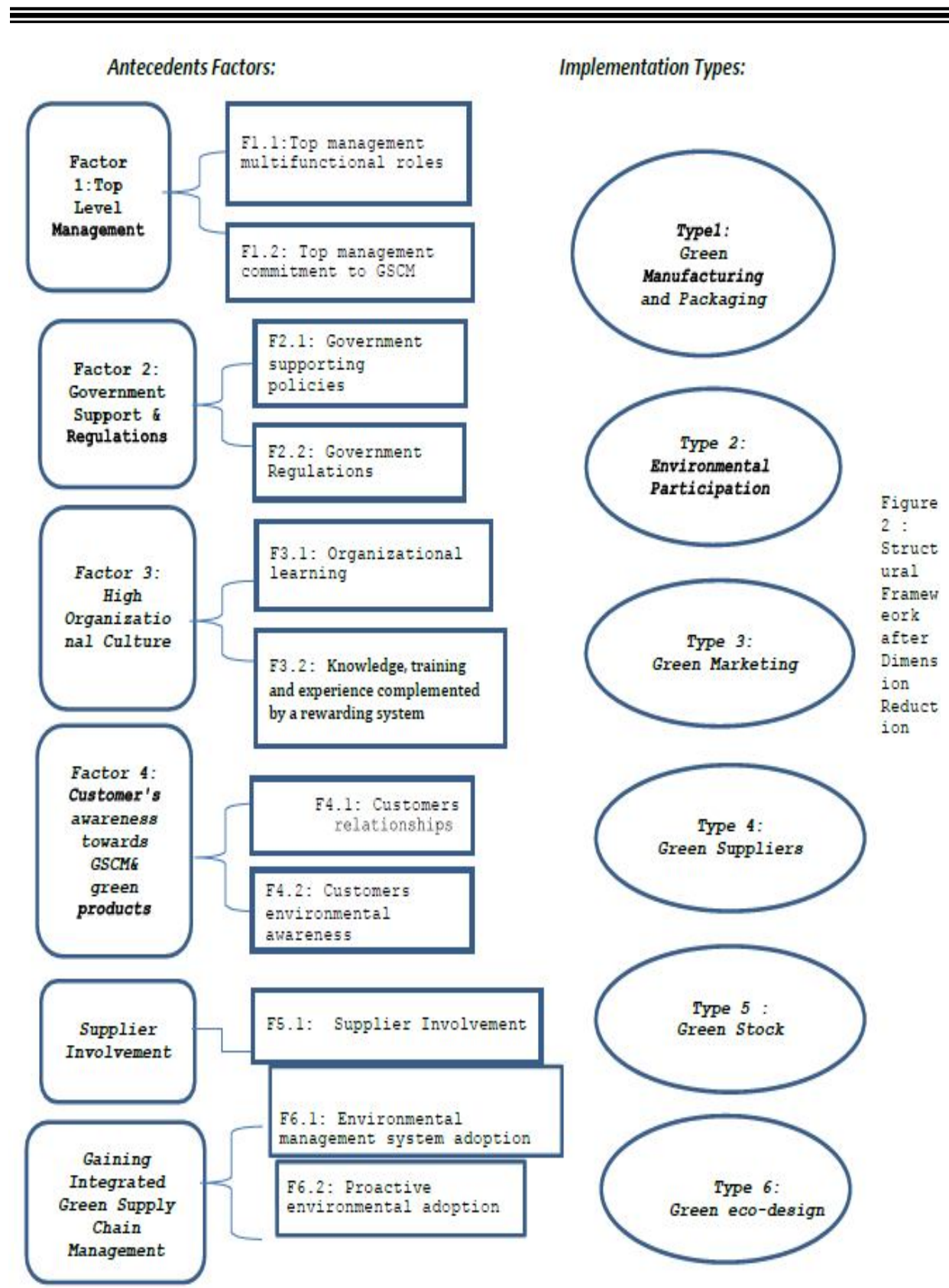

Figure 2: Factor analysis results 


\section{Dr. Rania Ramadan Moawad \& Dina Ramadan}

\subsubsection{Results for the structural model:}

\subsubsection{Hypothesis testing:}

Hypothesis 1: There is a relationship between top level management commitment to GSCM, and GSCM adoption practices (Implementation):

- H1a: Top management multifunctional roles, has a significant impact on GSCM adoption practices \& implementation.

- H1b: Top management commitment to GSCM, has a significant impact on GSCM adoption practices \& implementation.

- This hypothesis is tested using the multivariate test model:

- The relation between FAC1-1 (Top management multifunctional roles) and type 5 is accepted as the significance value $=0.005$, so it is accepted at 0.05 level, but the relation between this antecedent and the other implementation types is not accepted as their significance values $>0.05$.

- The relation between FAC1-2 (Top management commitment to GSCM) and types: 1,5,6 is accepted as their significance value < 0.05 , but the relation between this antecedent and the other implementation types is not accepted as their significance values $>$ 0.05 .

\section{Hypothesis 2: There is a relationship between Government support and regulations and GSCM adoption practices (implementation):}

- H2a: Government supporting policies has a significant impact on GSCM adoption practices \& implementation.

- H2b: Governmental regulations, has a significant impact on GSCM adoption practices \& implementation.

- This hypothesis is tested using the multivariate test model:

- The relation between FAC2-1 (Government supporting policies) and types $1,2,3$ is accepted as the significance value is $<0.05$, so it is accepted at 0.05 level, but the relation between this antecedent and the other implementation types are not significant as their significance 
Scientific Journal for Financial and Commercial Studies and Researches

(SJFCSR) Faculty of Commerce - Damietta University

values $>0.05$.

- The relation between FAC2-2 and type 1 is accepted as the significance value $=0.01$, so it is accepted at 0.05 level, but the relation between this antecedent and the other implementation types are not significant as their significance values $>0.05$.

\section{Hypothesis 3: There is relationship between High Organizational}

Culture (organization's internal culture), and GSCM adoption practices (Implementation).

- H3a: Organizational learning has a significant impact on GSCM adoption practices \& implementation.

- H3b: Knowledge, training and experience complemented by a rewarding system, has a significant impact on GSCM adoption practices \& implementation.

- This hypothesis is tested using the multivariate test model:

- The relation between FAC3-1 (Organizational learning) and type 2 is accepted as the significance value $=0.048$, so it is accepted at 0.05 level, but the relation between this antecedent and the other implementation types are not significant as their significance values $>0.05$.

- The relation between FAC3-2 (Knowledge, training and experience complemented by a rewarding system) and all the implementation types is not accepted, as their significance values $>0.05$.

Hypothesis 4: There is no relationship between Customer's awareness towards GSCM \& green products, and GSCM adoption practices (Implementation).

- H4a: Customers' relationship has a significant impact on GSCM adoption practices \& implementation.

- H4b: Customers Environmental Awareness has a significant impact on GSCM adoption practices \& implementation. 


\section{Dr. Rania Ramadan Moawad \& Dina Ramadan}

- This hypothesis will be tested using the multivariate test model:

- The relation between FAC4-1 (Customers' relationship) and all the implementation types is accepted as their significance value $<0.05$.

- The relation between FAC4-2 (Customers Environmental Awareness) and type 3, 4, 6 is accepted as their significance values $<0.05$, but the relation between this antecedent and the other implementation types are not accepted as their significance values $>$ 0.05 .

\section{Hypothesis 5: There is relationship between Supplier Involvement, and GSCM adoption practices (Implementation).}

- H5: Supplier involvement has a significant impact on GSCM adoption practices \& implementation.

- This hypothesis will be tested using the multivariate test model:

- The relation between FAC5-1 (Supplier involvement) and all the implementation types is not accepted as their significance value $>0.05$.

\section{Hypothesis 6: There is a relationship between Gaining Integrated} GSCM, and GSCM adoption practices (Implementation).

- H6a: Environmental Management System Adoption has a significant impact on GSCM adoption practices \& implementation.

- H6b: Proactive Environmental Strategy has a significant impact on GSCM adoption practices \& implementation.

- This hypothesis is tested using the multivariate test model:

- The relation between FAC6-1 (Environmental Management System Adoption) and all the implementation types is not accepted as their significance value $>0.05$.

- The relation between FAC6-2 (Proactive Environmental Strategy) and all the implementation types is not accepted as their significance value $>0.05$. 
Scientific Journal for Financial and Commercial Studies and Researches

(SJFCSR) Faculty of Commerce - Damietta University

Hypothesis 7: There is a relationship between all the proposed antecedents and GSCM implementation as a whole.

\section{- This hypothesis is tested using the univariate test model:}

The relation is accepted between the implementation as a whole and these antecedents' factors: FAC1_1 (Top management multifunctional roles)

,FAC1_2(Top management commitment to GSCM),FAC2_1 (Government supporting policies),FAC2_2 (Governmental regulations),FAC3_1 (Organizational learning),FAC4_1 (Customers' relationship),FAC $\overline{4} \_$(Customers Environmental Awareness; as their significance value $<0.05$. But the relation between the implementation and the other antecedents' factors is not accepted as their significance value $>0.05$.

\subsubsection{Parameter Estimation of the Multivariate Model:}

- We can conclude from the previous study that the factors ' components (independent variables) which have a significant effect on the dependent variables (implementation types from type 1 to type 6) are the following:

FAC1_1 (Top management multifunctional roles),

FAC1_2 (Top management commitment to GSCM) FAC2_1 (Government supporting policies) FAC2_2 (Governmental regulations)

FAC3_1 (Organizational learning)

FAC4_1 (Customers'relationship)

FAC4_2 (Customers Environmental Awareness)

Therefore, we consider only these 7 factors' components in the multivariate analysis

- This method will consider the impacts of all the independent variables on the dependent variables.

- This method will also produce a linear model for each dependent variable as a function of its corresponding inputs; it means it has to estimate the parameters (coefficients) associated with input variables. 


\section{Dr. Rania Ramadan Moawad \& Dina Ramadan}

The final structural model obtained is:

- Type 1 (Green Manufacturing and Packaging)=

0.374 FAC1_2 (Top management commitment to GSCM)+

0.347 FAC2_1 (Government supporting policies)+

0.374 FAC2_2 (Governmental regulations)+

0,275 FAC4_1 (Customers' relationship).

- Type 2 (Environmental Participation) $=0.313$ FAC2_1

(Government supporting policies) $+\mathbf{0 . 2 3 0}$ FAC3_1

(Organizational learning) + 0.649 FAC4_1 (Customers' relationship).

- Type 3 (Green Marketing) = 0.731 FAC2_1 (Government supporting policies) $+\mathbf{0 . 3 5 7}$ FAC4_1 (Customers $^{\prime}$ relationship). +0.312 FAC4_2 (Customers Environmental Awareness).

- Type 4 (Green Suppliers) $=0.265$ FAC4_1 (Customers' relationship) +0.391 FAC4_2 (Customers Environmental Awareness).

- Type 5 (Green Stock) $=0.375$ FAC1_1 (Top management multifunctional roles), $+\mathbf{0 . 4 7 2} \boldsymbol{F} \boldsymbol{A C} \overline{\mathbf{1}} 22$ (Top management commitment to GSCM) $+0.327 \overline{\boldsymbol{F}} \boldsymbol{A C 4} \mathbf{1}$ (Customers' relationship).

- Type 6 (Green Design) = 0.559 FAC1_2 (Top management commitment to GSCM) $+\mathbf{0 . 4 9 5}$ FAC4_1 (Customers' relationship) +0.341 FAC4_2 (Customers Environmental Awareness).

\subsubsection{Parameter Estimation of Univariate Model:}

In this study, we consider the GSCM implementation as a one dependent variable. To produce this model, we used the univariate analysis method.

IMPLEMENTATION $=$ 0.751FAC1_1 (Top management multifunctional roles) $+1.416 \mathrm{FAC1} 2$ (Top management commitment to 
Scientific Journal for Financial and Commercial Studies and Researches (SJFCSR) Faculty of Commerce - Damietta University

GSCM) + 1.407FAC2 1 (Government supporting policies) + 0.922FAC2_2 (Governmental regulations), + 0.313FAC3_1 (Organizational learning) + 2.273FAC4_1 (Customers' relationship) + 1.559FAC4_2 (Customers Environmental Awareness).

\subsubsection{Final Detailed Structural Model:}

The relation between the dependent variables (type 1, type 2, type 3 , type 4, type 5 and type 6) with the independent variables (: FAC1_1, FAC1 2, FAC2 1, FAC2 2, FAC3 1, FAC3 2, FAC4 1, FAC4 2, FAC5 1, FAC6 1, FAC6 2.) is shown in figure 3.

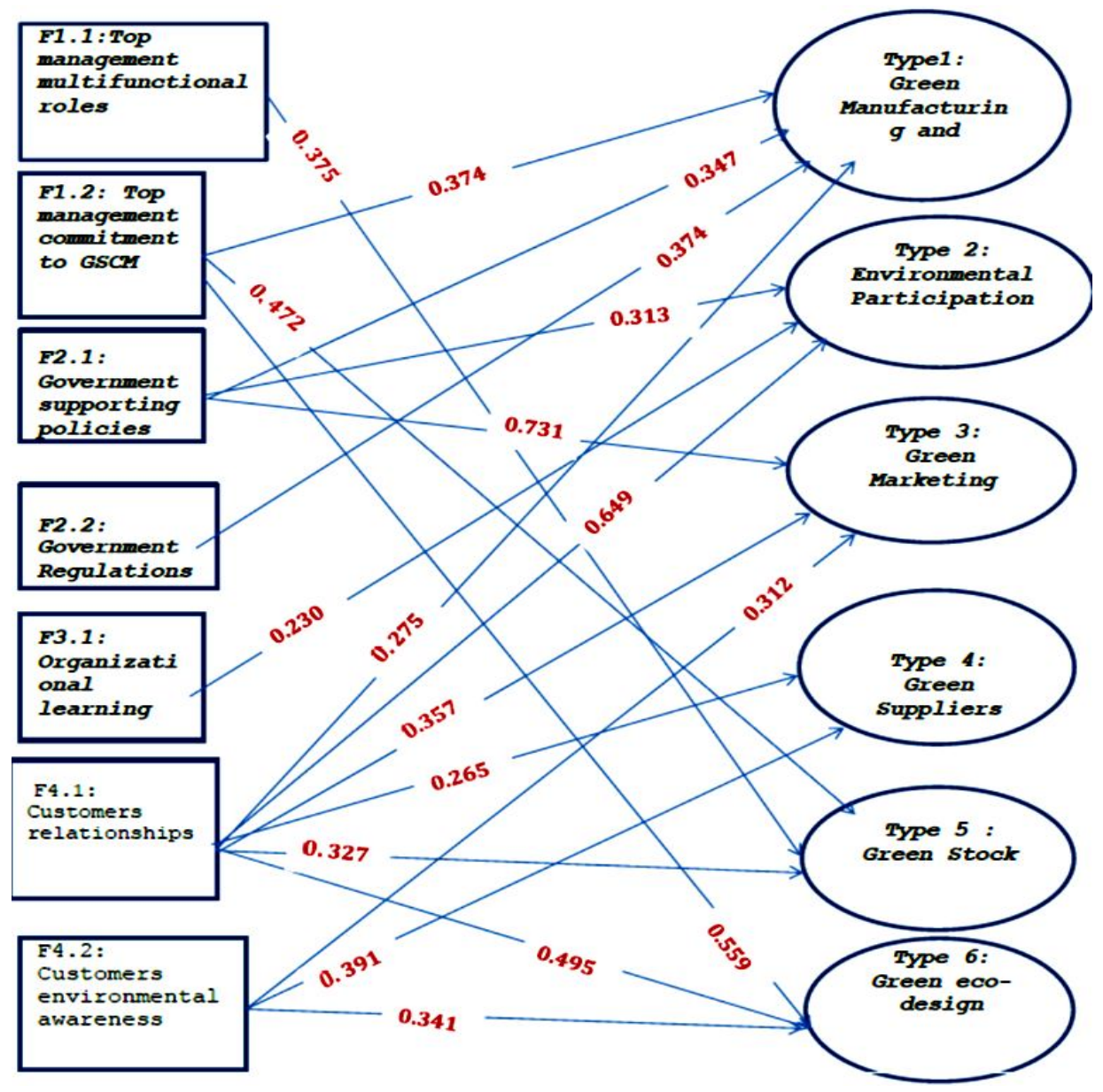

Figure 3: Final Detailed Structural Model 


\section{Dr. Rania Ramadan Moawad \& Dina Ramadan}

\subsubsection{Final Integrated Structural Model:}

The relation between the dependent variable: IMPLEMENTATION with the independent variables (factors' components): FAC1_1, FAC1_2, FAC2_1, FAC2_2, FAC3_1, FAC3_2, FAC4_1, FAC4_2, FAC5 Is shown in figure 4.

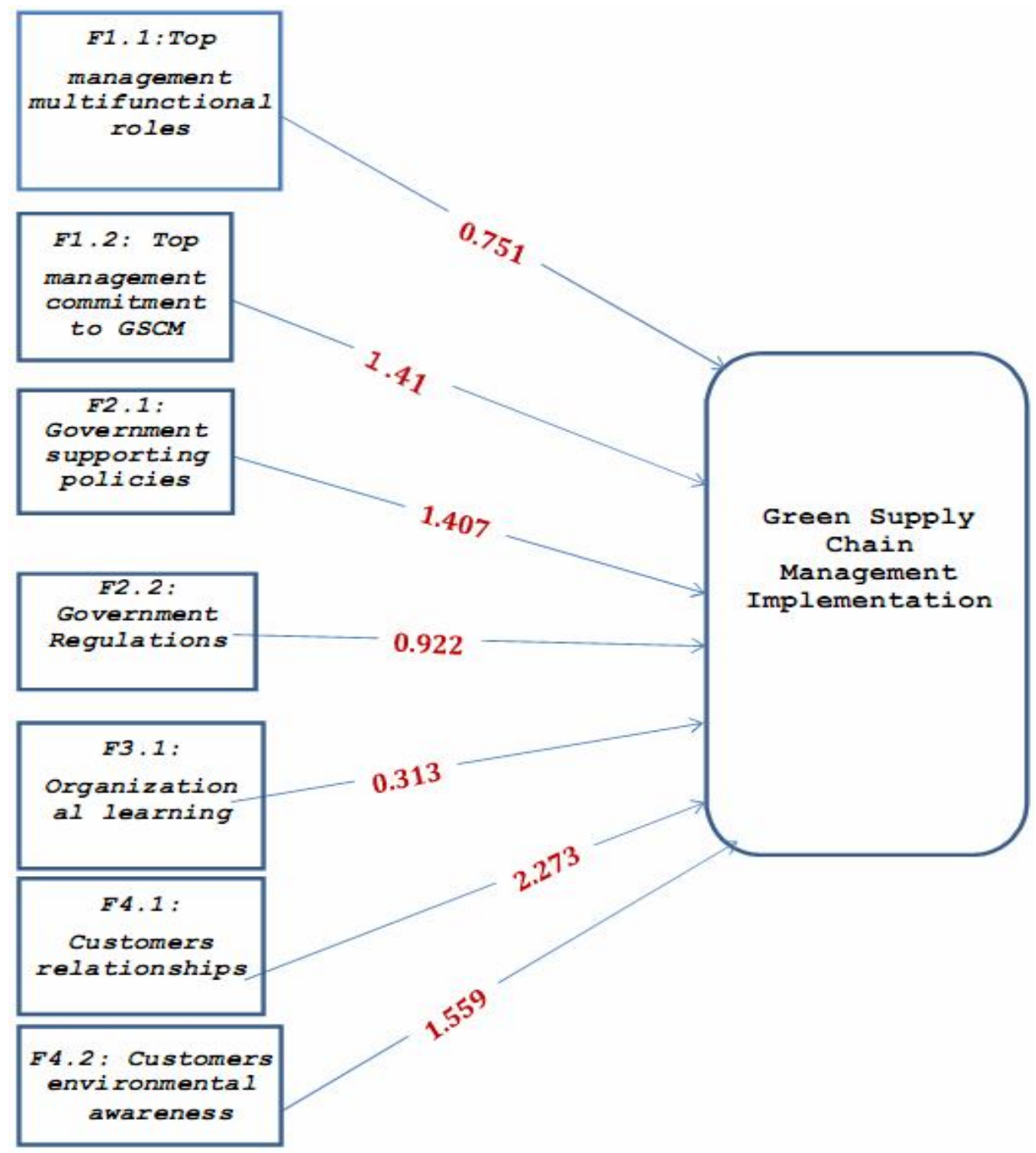


Scientific Journal for Financial and Commercial Studies and Researches

(SJFCSR) Faculty of Commerce - Damietta University

Figure 4: Final Integrated Structural Model

5. Conclusions

\subsection{Main findings}

The main finding of this study is that eight hypotheses out of twelve hypotheses are supported statistically and only four hypotheses are not supported.

\section{The accepted hypotheses are:}

- Top management multifunctional roles, has a significant impact on GSCM adoption practices \& implementation.

- Top management commitment to GSCM, has a significant impact on GSCM adoption practices \& implementation.

- Government supporting policies has a significant impact on GSCM adoption practices \& implementation.

- Governmental regulations, has a significant impact on GSCM adoption practices \& implementation.

- Organizational learning has a significant impact on GSCM adoption practices \& implementation.

- Customers' relationship has a significant impact on GSCM adoption practices \& implementation.

- Customers Environmental Awareness has a significant impact on GSCM adoption practices \& implementation.

- The relation is accepted between the implementation as a whole and these 7 antecedents' factors only: FAC1_1, FAC1_2, FAC2_1, FAC2_2, FAC3_1, FAC4_1 and FAC4_2.

\section{The rejected hypotheses are:}

- Knowledge, training and experience complemented by a rewarding system, has not a significant impact on GSCM adoption practices \& implementation.

- Supplier involvement has not a significant impact on GSCM adoption practices \& implementation 


\section{Dr. Rania Ramadan Moawad \& Dina Ramadan}

- Environmental Management System Adoption has not a significant impact on GSCM adoption practices \& implementation

- Proactive Environmental Strategy has not a significant impact on GSCM adoption practices \& implementation

- Limitations of the study are:

- The findings and results cannot be generalized as the questionnaire focuses only on the electrical \& electronics sector, so it does not encompass the other different sectors.

- The questionnaire addresses only six antecedents which were mentioned in the paper as the important ones.

These results are convenient because as the environmental awareness is increasing, firms are facing heavy pressure from different stakeholders including government and customers to mitigate their harmful effect on the environment. Internal management is a key critical success factor for enterprises to adopt green practices. Pressure employees bring about, encouragement and support from environmentalprotection motivate senior management. Customers' relationship and environmental awareness play an important and effective part .Indeed; developing nations' firms are facing heavy pressure to adopt green practices in their business operations of supply chain to meet their customers' demand so that they can be competitive in the market. Governments should establish strict environmental laws to control climate change, global warming and pollution; and firms are required to reduce their supply chain's negative effect on environmental sustainability. Hence, it becomes more and more important for firms in supply chain to have conformity with regulations.

Providing the right education about sustainability and GSCM to the companies' employees and stakeholders would raise their knowledge, awareness and their commitment in the implementation process. This would consequently support the companies in reducing the resistance to change which is one of the most challenging barriers. 
Scientific Journal for Financial and Commercial Studies and Researches (SJFCSR) Faculty of Commerce - Damietta University

\subsection{Comparison of research findings with previous studies}

Table 2: Comparison between research findings \& previous studies

\begin{tabular}{|c|c|c|c|}
\hline Author & title & Antecedents & Practices \\
\hline $\begin{array}{l}\text { Sirkanta } \\
\text { Routrooy } \\
-2009\end{array}$ & $\begin{array}{l}\text { Antecedents and } \\
\text { drivers for green } \\
\text { supply chain } \\
\text { management } \\
\text { implementation } \\
\text { in manufacturing } \\
\text { environment }\end{array}$ & $\begin{array}{l}\text { 1-Top management } \\
\text { commitment } \\
\text { 2-Government's initiative } \\
\text { 3- Customer Awareness }\end{array}$ & $\begin{array}{l}\text { 1- Green design } \\
\text { 2- Green operations } \\
\text { 3- Green sourcing } \\
\text { 4- Green packaging } \\
\text { 5- Reverse Logistics } \\
\text { 6- Environmental } \\
\text { management system } \\
\text { (EMS) } \\
\text { 7- Green innovation }\end{array}$ \\
\hline $\begin{array}{l}\text { Arvind } \\
\text { Upadhyay } \\
, 2012\end{array}$ & $\begin{array}{l}\text { Antecedents and } \\
\text { Enablers of Green } \\
\text { Supply Chain } \\
\text { Practices }\end{array}$ & $\begin{array}{l}\text { 1-Addressing } \\
\text { environmental } \\
\text { consideration } \\
\text { 2-Strong upstream- } \\
\text { downstream cooperation } \\
\text { and integration } \\
\text { 3- Application } \\
\text { continuous improvement } \\
\text { models } \\
\text { 4- Internal improvement of } \\
\text { product or processes } \\
\text { 5- Developing green } \\
\text { standards and } \\
\text { specifications for design } \\
\text { 6- Resale of assets via } \\
\text { online disposition } \\
\text { avenues }\end{array}$ & $\begin{array}{l}\text { 1- Environmental } \\
\text { certification } \\
\text { 2- Pollution prevention } \\
\text { 3- Life cycle } \\
\text { 4- assessment (LCA) 4- } \\
\text { Design for the } \\
\text { environment } \\
\text { 5- Reverse logistics } \\
\text { 6- Internal } \\
\text { environmental } \\
\text { management } \\
\text { 7- Green purchasing } \\
\text { 8- Cooperation with } \\
\text { customer including } \\
\text { environment } \\
\text { requirement } \\
\text { 9- Investment recovery } \\
\text { 10- Eco-design } \\
\text { practices }\end{array}$ \\
\hline $\begin{array}{l}\text { The } \\
\text { Researcher } \\
\mathrm{r}, 2017\end{array}$ & $\begin{array}{l}\text { Antecedents of } \\
\text { Green Supply } \\
\text { Chain } \\
\text { Management } \\
\text { Implementation }\end{array}$ & $\begin{array}{l}\text { 1- } \text { Top management } \\
\text { multifunction al rules } \\
\text { (FAC1-1) } \\
\text { 2- Top management } \\
\text { commitment to } \\
\text { GSCM (FAC1-2) } \\
\text { 3- Government } \\
\text { supporting policies } \\
\text { (FAC2 } \\
\text {-1) }\end{array}$ & $\begin{array}{l}\text { 1-Green Manufacturing } \\
\text { and Packaging (Type } \\
\text { 1) } \\
\text { 2-Environmental } \\
\text { Participation (Type } \\
\text { 2) } \\
\text { 3- Green Marketing } \\
\text { (Type 3) } \\
\text { 4- Green Supplier (Type } \\
\text { 4) } \\
\text { 5- Green Stock (Type 5) } \\
\text { 6- Green eco-design } \\
\text { (Type 6) }\end{array}$ \\
\hline & & $\begin{array}{l}\text { 4-Government } \\
\text { Regulations (FAC2-2) } \\
\text { 5-Organizational learning }\end{array}$ & \\
\hline
\end{tabular}




\section{Dr. Rania Ramadan Moawad \& Dina Ramadan}

\begin{tabular}{|c|c|c|c|}
\hline Author & title & Antecedents & Practices \\
\hline & & $\begin{array}{l}\text { (FAC 3-1) } \\
\text { 6- Knowledge, training } \\
\text { and experience } \\
\text { complemented by a } \\
\text { rewarding system } \\
\text { (FAC3- 2) } \\
\text { 7- Customer's } \\
\text { relationships (FAC4- } \\
\text { 1) } \\
\text { 8- Customers } \\
\text { environmental } \\
\text { awareness (FA C4-2) } \\
\text { 9- Supplier Involvement } \\
\text { (FAC5-1) } \\
\text { 10- Proactive } \\
\text { environmental adoption } \\
\text { (FAC 6-1) } \\
\text { 11- Environmental } \\
\text { management system } \\
\text { adoption (FAC6-2) }\end{array}$ & \\
\hline
\end{tabular}

\section{Recommendations \& Further Research Directions:}

As the green supply chain management is a new area in electrical \& electronics sector in Egypt, much research is still at the theoretical level and little has been proved within this sector. Therefore, it is also too early to investigate the long-term benefits for the sustainable development but just only the perception of these companies.

\subsection{Managerial Implications:}

Egypt can be a potential market for recycling e-waste due to the massive quantities generated from the consumption in the electronic and electrical sector. Thus, some recommended actions are provided for the stakeholders within the supply chains of electronic and electrical industries in Egypt for e- waste recycling and green supply chain management support to assure a clean environment.

These recommended actions can be formulated in the following action plans: 
Scientific Journal for Financial and Commercial Studies and Researches (SJFCSR) Faculty of Commerce - Damietta University

Table 3: Managerial Implications (Action Plans)

\begin{tabular}{|c|c|c|}
\hline Action & Responsible & Procedure \\
\hline $\begin{array}{l}\text { 1- Establishment of } \\
\text { institutional framework }\end{array}$ & $\begin{array}{l}\text { Egyptian } \\
\text { government }\end{array}$ & $\begin{array}{l}\text { - Setting up policies, legislations, and } \\
\text { enforcement means, } \\
\text { - Developing a cost-recovery } \\
\text { mechanism. } \\
\text { - Creating programs for capacity } \\
\text { building and awareness for the } \\
\text { GSCM. }\end{array}$ \\
\hline $\begin{array}{l}\text { 2- Policy and planning of } \\
\text { GSCM strategy }\end{array}$ & $\begin{array}{l}\text { Public \& private } \\
\text { sectors top } \\
\text { management }\end{array}$ & $\begin{array}{l}\text { - Strategy planning. } \\
\text { - Strategy implementation \& control. }\end{array}$ \\
\hline $\begin{array}{l}\text { 3- } \text { Finance and cost } \\
\text { recovery arrangements }\end{array}$ & Governorates & $\begin{array}{l}\text { - Allocate their respective e- waste } \\
\text { budget, with limited portion of the } \\
\text { waste handling fees to be collected } \\
\text { through the electricity bill. }\end{array}$ \\
\hline $\begin{array}{l}\text { 4- Encouraging suppliers' } \\
\text { involvement }\end{array}$ & $\begin{array}{l}\text { Manufacturing } \\
\text { organizations }\end{array}$ & $\begin{array}{l}\text { - Selecting suppliers based on their } \\
\text { green practices. } \\
\text { - involving Suppliers in GSCM } \\
\text { improvement/development process. } \\
\text { - Providing Suppliers with } \\
\text { environmental and economic } \\
\text { benefits from the GSC initiatives. }\end{array}$ \\
\hline $\begin{array}{lr}5-\text { Increase } & \text { customer's } \\
\text { awareness } & \text { towards } \\
\text { GSCM \& green products }\end{array}$ & Media & $\begin{array}{l}\text { - Promotion programs. } \\
\text { - Awareness programs about the } \\
\text { features that green products provide. } \\
\text { - Obtain relevant and helpful } \\
\text { information from customers on how } \\
\text { to comply with their } \\
\text { - environmental requirements }\end{array}$ \\
\hline
\end{tabular}




\section{Dr. Rania Ramadan Moawad \& Dina Ramadan}

\section{References}

Abhijit Majumdar, Sanjib Sinha, 2018, Modeling the barriers of green supply chain management in small and medium enterprises: A case of Indian clothing industry, Management of Environmental Quality journal, Emirald publishing, ISSN: 1477-7835, 10 September 2018.

Bhateja A., Babbar R. et al., (2011), Study of Green Supply Chain Management in the Indian Manufacturing Industries, A Literature Review cum an Analytical Approach for the measurement of Performance, International Journal of Computational Engineering and Management, Vol. 13, pp.87-90

BaofengHuo, MinhaoGu, , ZhiqiangWang ,2019, Green or lean? A supply chain approach to sustainable performance, journal of cleaner production, Elsevier, https://doi.org /10. 1016 /j.jclepro.2019.01.141

B. P. Sharma and M. D. Singh, 2015, Modeling the Knowledge Sharing Barriers: An ISM Approach, International Journal of KnowledgeBased Organizations archive Volume 5 Issue 1, IGI Publishing Hershey, PA, USA, doi>10.4018/ijkbo.2015010102

B.-Y. Chang, Y. Kenzhekhanuly, B. Park , 2013, A study on determinants of green supply chain management practice ,International Journal of Control and Automation 6(3):199-208

Cheng Ling Tan, Suhaiza Zailani, Sieow Chin Tan, Mohd Rizaimy Shaharudin , 2016, The impact of green supply chain management practices on firm competitiveness, International Journal of Business Innovation and Research, pp539-558, DOI: 10.1504 /IJBIR. 2016.079507.

Chieh-Yu Lin, Syed Shah Alam, Yi-Hui Ho, Mohammed Emad AlShaikh and Parves Sultan, 2020 , Adoption of Green Supply Chain Management among SMEs in Malaysia, doi:10.3390/su12166454, www.mdpi.com/journal/sustainability

Chien M., and Shih L., (2007), An empirical study of the implementation of green supply chain management practices in the electrical and electronic industry and their relation to organizational 
Scientific Journal for Financial and Commercial Studies and Researches (SJFCSR) Faculty of Commerce - Damietta University

performances, International Journal of Environmental Science and Technology, Vol.4, No.,3, pp. 383-394.

Dashore K., and Nagendra S., 2013, Green Supply Chain Management, A Hierarchical Framework for Barriers, International Journal of Engineering Trends and Technology (IJETT) - Vol. 4I, No.5, pp.2174-2175.

Djunaidi, M. Abdul Azis Sholeh, and Nur Muhammad Mufiid, 2018, Analysis of green supply chain management application in Indonesian wood furniture industry Cite as: AIP Conference Proceedings 1977, 020050 (2018); https://doi.org/10.1063/1. 5042906, Published Online: 26 June.

ElBeheiry H., (2012), Drivers and Barriers Facing Adoption of Green Supply Chain Management in Egyptian Food and Beverage Industry, White Paper, College of International Transport and Logistics, Arab Academyfor Science Technology and Maritime Transport, pp. 3-6.

Elting J., 2009, Green Supply Chain Management in Manufacturing Companies in New Zealand, A Comparative Case Study Analysis, A Thesis Submitted in Partial Fulfillment of The Requirements for the Degree of Master of Business, p.14.

Fortes J., (2009), Green Supply Chani Management, A Literature Review, Otago Management Graduate Review, Vol.7, pp. 57.

Gupta V., Abidi N. et al., (2013), Green Supply Chain Management Initiatives by IT Companies in India" , IUP Journal of Operations Management, Vol. 12, No. 2, pp. 6-7.

Hashemi S. et al., (2014), Agrey-based carbon management model for green supplier selection, Vol.26, No.2, p.125.

Juthathip Suraraksa and Kwang Sup Shin, 2019, Comparative Analysis of Factors for Supplier Selection and Monitoring: The Case of the Automotive Industry in Thailand, doi: 10.3390/su11040981

Available@ www.mdpi.com/journal/sustainability.

Kangangi M., (2013), Green supply chain implementation, best practices and challenges, school of business university of Nairobi, p.p.,3-10. 


\section{Dr. Rania Ramadan Moawad \& Dina Ramadan}

Kannan G., Devika K., Noorul A., 2010, Analyzing supplier development criteria for an automobile industry, Industrial Management and Data Systems, Vol.110, No.1, pp. 43-62.

Karen Wessels, Samuel Robinson, 2018, the Evolution of Benefits, published by SHRM; the Society for Human Resource Management (SHRM).

King A., and Barker A., (2007), Using the Delphi Technique to Establish a Robust Research Agenda for Remanufacturing, Advances in Life Cycle Engineering for Sustainable Manufacturing Businesses, Springer, London, pp. 219-224.

Kumar R., and Chandrakar R., (2012), Overview of Green Supply Chain Management, Operation and Environmental Impact at Different Stages of the Supply Chain, International Journal of Engineering and Advanced Technology, Vol.1, No.3, p.1.

M. K. Mishra, D. Choudhury, K.S.V. Copal Rao, 2019, impact of SMEs Green Supply Chain Practice Adoption on SMEs Firm and Environmental Performance, Theoretical economics letters, Vol 9 no. 6, DOI: 10.4236

Metters R.,Metters K .K., Pullman M., and Walton S., (2006), Service Operations Management, South- Western Cengage Learning, Florence.

Mochamad Agung Wibowo, Naniek Utami Handayani, Anita Mustikasari, Asri Nurdiana, 2018, Determining Factors for Implementing Green Supply Chain Management in the Construction Industry: A Literature Review, Article in MATEC Web of Conferences, January 2018 DOI: $10.1051 /$ matecconf $/ 201815902038$

Muhammad Salman Asif, Henry Lau, Dilupa Nakandala, Youqing Fan *, Hilal Hurriyet, 2020, Adoption of green supply chain management practices through collaboration approach in developing countries - From literature review to conceptual framework.,Journal of Cleaner Production 276 (2020) 124191,Elsevier.

Ninlawan C. et al., (2010), The Implementation of Green Supply Chain Management Practices in Electronics Industry, Vol.3, pp.1-6. 
Scientific Journal for Financial and Commercial Studies and Researches (SJFCSR) Faculty of Commerce - Damietta University

Raganathan H. and Premukar H., 2012, Improving Supply Chain Performance through Lean and Green, A study at Volvo Group India and Sweden, A Master Thesis Program in Production and Logistics, pp.19-40.

Routroy S., 2009, Antecedents and Drivers for Green Supply Chain Management Implementation in Manufacturing Environment, ICFAI Journal of Supply Chain Management, Vol. 6 No. 1, pp. 2022.

Sarkis J., (1999), how green is the supply chain, Practice and research, pp. 3-5.

Shreejith B., 2012, A Hierarchical Framework of Barriers to Green Supply Chain Management in the Construction Sector, Journal of Sustainable Development, Vol. 5, pp. 15-27.

Singh M. D. and Kant R., 2012, Knowledge management barriers, An interpretive structural modeling approach, International Journal of Management Science and Engineering Management, Vol.3, No. 3, pp. 141-150.

Soh Hyun Chu , Hongsuk Yang, Mansokku Lee 2and Sangwook, 2017, Article The Impact of Institutional Pressures on Green Supply Chain Management and Firm Performance: Top Management Roles and Social Capital, Academic Editor: Giuseppe, doi:10.3390 / su90507 64 www.mdpi.com/journal/ sustainability

Srivastava, S. K. 2007, Green supply-chain management, A state-of-theart literature review", International Journal of Management Reviews, Vol. 9, No.1, pp. 53-80.

Srivastava S. K. and Srivastava R. K., 2006, Managing Product Returns for Reverse Logistics, International Journal of Physical Distribution and Logistics Management, Vol. 36, No. 7, pp. 524-546.

Sunil Dhull, M.S. Narwal, 2016, Drivers and barriers in green supply chain management adaptation: A state-of-art review , Growing Science Ltd. Doi: 10.5267/j.uscm.2015.7.003

Syed Shakil Ahmed, Tauhima Akter and Yuchao Ma, 2018, Green Supply Chain Management (GSCM) Performance Implemented by 


\section{Dr. Rania Ramadan Moawad \& Dina Ramadan}

the Textile Industry of Gazipur District, Dhaka", DOI: 10.3390/ logistics2040021@available @ www. mdpi.com /journal /logistics

Upadhyay A., 2012, Antecedents and enablers for green supply chain practices, A PHD Thesis, p.18.

Vachon S. and Robert D., 2006, Extending green practices across the supply chain, International Journal of Operations and Production Management, Vol. 26 No.7, pp. 795-821.

Wang F., Huisman J., Meskers C., Schluep M., Stevels A., Hagelüken C., 2012, The Best- of Worlds philosophy, Developing local dismantling and global infrastructure network for sustainable ewaste treatment in emerging economies.

Xianbiag L., Jie Y., Sixiao Q., Leina W., Tomohiro S. and Cunkuan B., 2011, Sustainable Production, Practices and Determinant Factors of Green Supply Chain Management of Chinese Companies, Business Strategy and the Environment, Vol.21, pp. 1- 16.

Yi-Hui Ho, Chieh-Yu Lin, 2014, An Empirical Study on Organizational Infusion of Green Practices in Chinese Logistics Companies, Journal of Economic and Social Studies, http://dx.doi.org/ 10.147 06/ JECOSS11427.

Yu-Lin C., and Hui Ho, Y., 2008, An Empirical Study on Logistics services provider, intention to adopt Green Innovations. Journal of Technology, Management and Innovation, Vol.3, No.1, pp. 17-26.

Zhijun Feng and Wei Chen, 2018, Environmental Regulation, Green Innovation, and Industrial Green Development: An Empirical Analysis Based on the Spatial Durbin Model, Sustainability journal, publisher MDPI, doi: 10.3390/su10010223available@ www.mdpi.com/journal/sustainability 
Scientific Journal for Financial and Commercial Studies and Researches (SJFCSR) Faculty of Commerce - Damietta University

\title{
نموذج هيكلي لإدارة سلسلتمالتوريد الخضراء يربط بين متطلبات إدارة سلسلتّا التوريد الخضراء وممارسات التطبيق
}

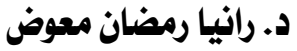

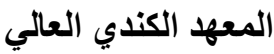 \\ دينا رمضان \\ أكاديمية السادات للطوم الإدارية
}

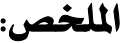

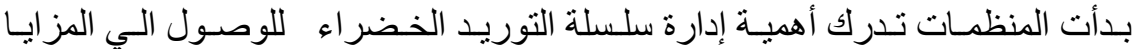

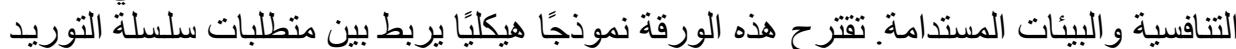

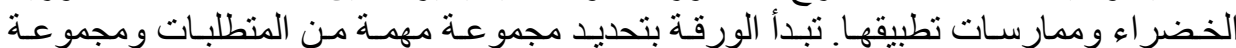

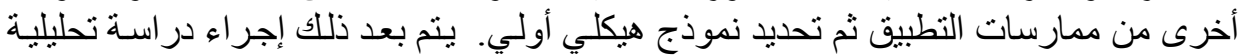

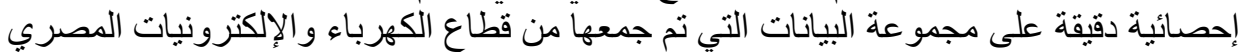

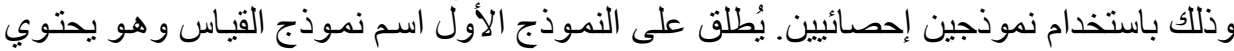

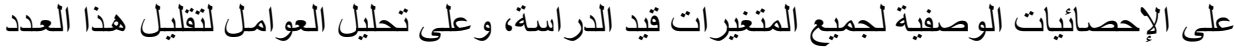

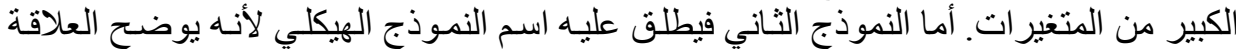

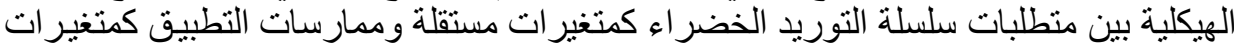

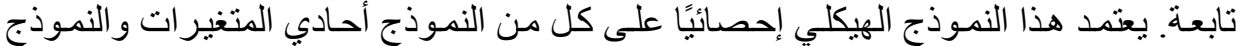

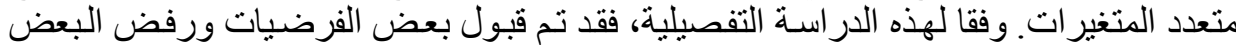

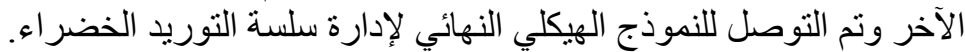

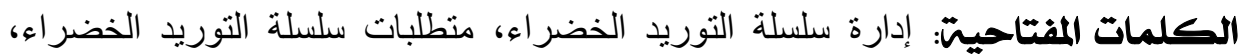

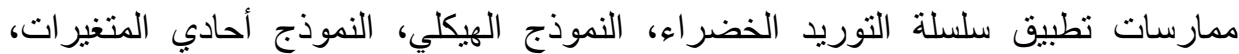

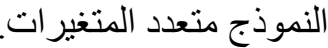

